\title{
Genicunolide A, B and C: three new triterpenoids from Euphorbia geniculata
}

\author{
Alia Farozi, Javid A. Banday ${ }^{*}$ and Shakeel A. Shah
}

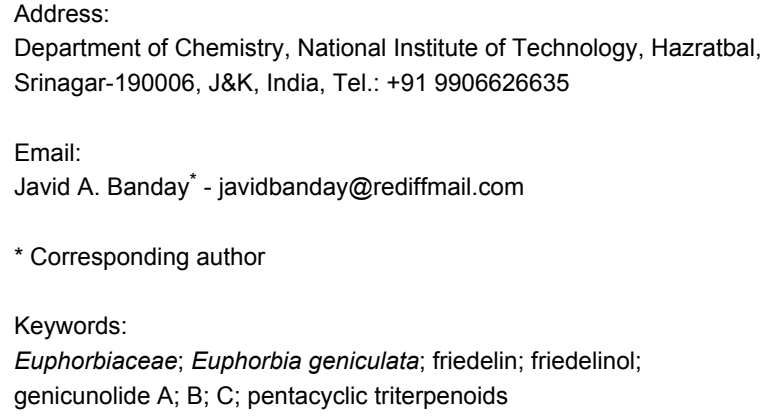

Beilstein J. Org. Chem. 2015, 11, 2707-2712.

doi:10.3762/bjoc. 11.291

Received: 28 August 2015

Accepted: 06 December 2015

Published: 23 December 2015

Associate Editor: S. Bräse

(c) 2015 Farozi et al; licensee Beilstein-Institut. License and terms: see end of document.

\begin{abstract}
Three new triterpenoids, designated as genicunolide A (1), B (2) and C (3), along with friedelin (4) and friedelinol (5), were isolated from the aerial parts of Euphorbia geniculata. They were characterized as $1 \beta$-acetoxy-3 $\beta$-hydroxy- $11 \alpha, 12 \alpha$-oxidotaraxer14-ene, $1 \beta, 3 \beta$-diacetoxy-21 $\alpha$-hydroxy-11 $\alpha, 12 \alpha$-oxidotaraxer-14-ene and $3 \beta, 9 \alpha, 20 \alpha$-trihydroxy- $\Psi$-taraxast-5-ene, respectively, by spectral and chemical methods.
\end{abstract}

\section{Introduction}

Euphorbia (Euphorbiaceae) is a very large and diverse genus of flowering plants comprising of about 2,000 members and is found all over the world, ranging from short annual plants to well developed tall trees [1].

The plants of the family Euphorbiaceae contain well-known skin irritating and tumor-promoting diterpenoids with tigliane, ingenane and daphnane skeletons [2]. Some of the species are used in folk medicine to cure skin diseases, gonorrhea, migraines, intestinal parasites, and warts [3] and as a purgative [4-6]. Several macrocyclic diterpenoids with antibacterial, anticancer, anti-multidrug-resistant, antifeedant, anti-HIV and analgesic activity have been isolated from different Euphorbia species. They include jatrophane, ingol and myrsinane diterpenoids [7-13].

Triterpenoids which have been reported from various species of Euphorbia include $\beta$-amyrin [1], $\beta$-amyrin acetate [14,18], cycloeucalenol, obtusifoliol, 24-methylenecycloartan-3- $\beta$-ol, $\beta$-sitosterol, betulin, erythrodiol, oleanolic acid, $\beta$-sitosterol glucoside[15], 29-norcycloart-5-ene-5,8-lanostadiene-3 $\beta$-ol, $3 \beta, 24 S, 25$-trihydroxycycloartane, $3 \beta, 24(R), 25$-trihydroxycycloartane, 24-methylenecycloartan-3 $\beta$-ol [16], cycloart-23ene-3,5-diol [17], lupeol, lupeol acetate, ginnone, ambrein, lupeone [18], 24-methylenecycloartanol [19], cycloart-25-en-

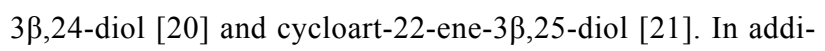


tion, nor-isoprenoids and coumarins have also been reported from few species of Euphorbia [22-24].

Euphorbia geniculata Orteg. [25,26], is a wild weed found in the Jammu region of India [27]. The plant is locally used for the treatment of bacterial infections and inflammations. Previous phytochemical investigations have demonstrated that this plant contains flavonoids: kaempferol, quercetin and 3-rhamnosyl quercetin [28] and triterpenes $\beta$-amyrin acetate [29] and geniculatin [30].

Reinvestigation of chemistry of the plant led to isolation of three new triterpenoids, designated as genicunolide A (1), B (2) and C (3), together with friedelin (4) [31] and friedelinol (5) [32], from the ethyl acetate extract of the aerial parts of the plant. Herein, we report the characterization of the three compounds by spectral and chemical methods.

\section{Results and Discussion}

The compounds 1-3 (Figure 1) responded positively to the characteristic Liebermann-Burchard [33], TCA [34,35] and TNM tests [35] for unsaturated triterpenoids.
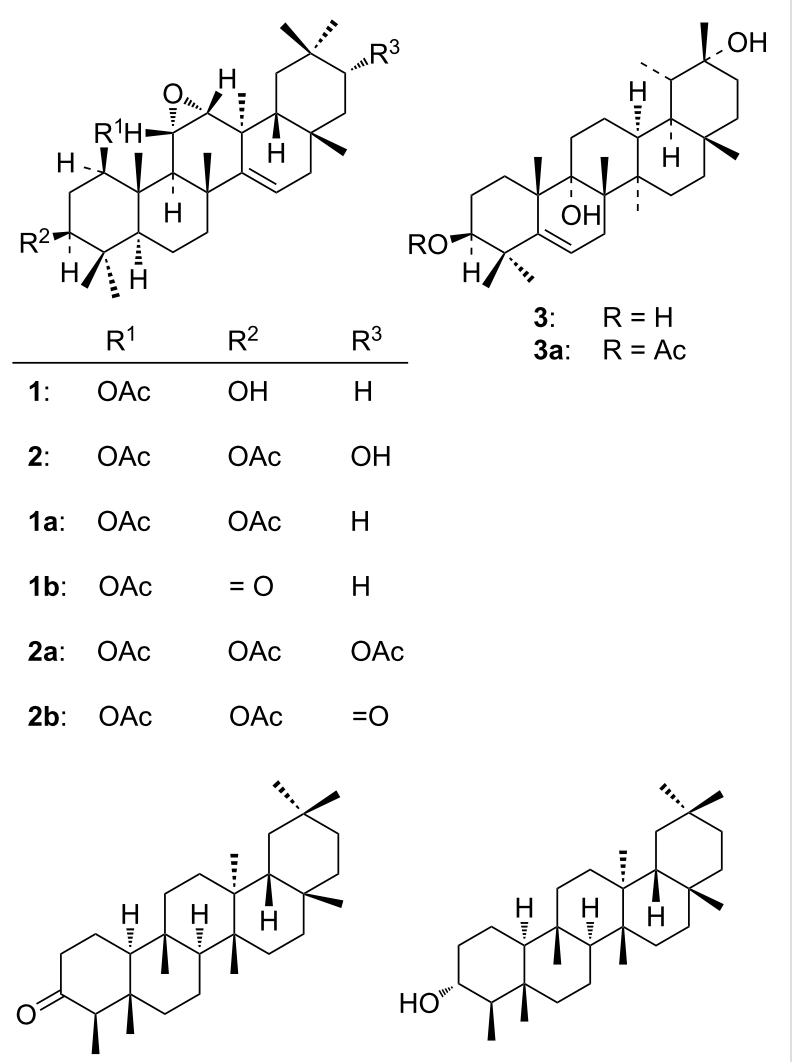

4

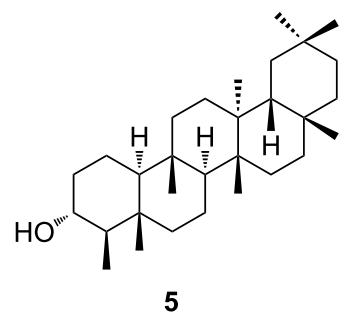

Figure 1: Structures of compounds 1, 2, 3, 1a, 2a, 1b, 2b, 3a, 4 and 5.
The compound $\mathbf{1}, \mathrm{M}^{+}$at $m / z 498.0695$ (calculated for $\mathrm{C}_{32} \mathrm{H}_{50} \mathrm{O}_{4}, 498.0700$ ), possessed eight tertiary methyl groups, an acetoxy functionality $\left[v_{\max } 1736 \mathrm{~cm}^{-1}, \delta 2.03(\mathrm{~s}, 3 \mathrm{H}), \delta_{\mathrm{C}}\right.$ $170.2,21.3]$, a trisubstituted double bond $\left[v_{\max } 1630,1042\right.$, $\left.880 \mathrm{~cm}^{-1}, \delta 5.56(\mathrm{~d}, J=5.2 \mathrm{~Hz}, 1 \mathrm{H}, \mathrm{H}-15)\right]$ [36] and a secondary equatorial hydroxy group $\left[v_{\max } 3500 \mathrm{~cm}^{-1}\right]$ whose carbinylic proton resonated at $\delta 3.16(\mathrm{dd}, J=8.1 \mathrm{~Hz}, 1 \mathrm{H}, \mathrm{H}-3)$. On acetylation with $\mathrm{Ac}_{2} \mathrm{O}-\mathrm{C}_{5} \mathrm{H}_{5} \mathrm{~N}$, at room temperature, compound 1 afforded the diacetate $1 \mathrm{a}, \delta 2.06(\mathrm{~s}, 6 \mathrm{H})$, and on oxidation with $\mathrm{CrO}_{3}-\mathrm{C}_{5} \mathrm{H}_{5} \mathrm{~N}$ yielded a ketoacetate $\mathbf{1 b}, v_{\max } 1738$, $1680 \mathrm{~cm}^{-1}, \delta_{\mathrm{C}} 216.7,170.8$, which responded positively to the characteristic Zimmermann test for 3-keto function [37], thereby placing the hydroxy group in compound 1 at $3 \beta$ position, $\delta_{\mathrm{C}} 77.2$ [38].

The mass spectrum of compound $\mathbf{1}$ displayed the characteristic features of the taraxer-14-ene skeleton [39] by exhibiting RDA fragment ion peaks at $m / z 374$ (rings $\mathrm{A} / \mathrm{B} / \mathrm{C}$ ) and 124 (ring E) and the vinylic carbon resonance signals at $\delta_{\mathrm{C}} 118.8(\mathrm{C}-15)$ and 157.0 (C-14) [40].

The presence of a cis-oxido functionality in compound $\mathbf{1}$ was evident from a pair of $\mathrm{AB}$ doublets at $\delta 2.82$ and $3.01\left(J_{\mathrm{ae}}=\right.$ 4.7 $\mathrm{Hz}, 1 \mathrm{H}$ each, $\mathrm{H}_{\mathrm{e}}-12$ and $\left.\mathrm{H}_{\mathrm{a}}-11\right)$, in its ${ }^{1} \mathrm{H}$ NMR spectrum, two methine carbon resonance signals at $\delta_{\mathrm{C}} 53.4(\mathrm{C}-11)$ and 58.3 (C-12) [41] and loss of $\mathrm{CO}$ and $\mathrm{H}_{2} \mathrm{O}$, via rearrangement of hydrogen [42] from the RDA fragment ion at $m / z 374$ to give abundant ion peaks at $m / z 346$ and 354, respectively.

The acetoxy functionality in compound $\mathbf{1}$ was placed at C-1 $\beta$-position on the basis of the chemical shift, multiplicity and coupling constant of the carbinylic proton $\left[\delta 4.53\left(\mathrm{dd}, J_{\mathrm{ae}}=\right.\right.$ $\left.\left.7.4 \mathrm{~Hz}, J_{\mathrm{aa}}=8.5 \mathrm{~Hz}, 1 \mathrm{H}, \mathrm{H}-1\right)\right]$ together with the identical chemical shift of $\mathrm{H}-1$ and $\mathrm{H}-3$, in the ${ }^{1} \mathrm{H}$ NMR spectrum of $\mathbf{1 a}$, and the comparable chemical shifts of C-1 and C-3 of $\mathbf{1 a}\left(\delta_{\mathrm{C}}\right.$ 80.7 and 80.6 , respectively) with that of $1 \beta, 3 \beta$-diacetoxylupenes [43].

The structure of compound 1 was further confirmed by ${ }^{1} \mathrm{H},{ }^{1} \mathrm{H}$ and ${ }^{1} \mathrm{H},{ }^{13} \mathrm{C}$ COSY, HMBC and HSQC experiments which allowed unambiguous fixation of protons to appropriate carbons and also ${ }^{13} \mathrm{C}$-chemical shifts (Table 1 ). The long range correlations between the protons at $\delta 1.96\left(\mathrm{H}_{\mathrm{a}}-2\right)$ and $1.98\left(\mathrm{H}_{\mathrm{e}}-2\right)$ and carbonyl signal at $\delta_{\mathrm{C}} 170.8$ confirmed the presence of acetoxy carbonyl at $\mathrm{C}-1$. This was further substantiated by the long range mutual coupling of the carbinylic proton at $\delta 4.53$ with the proton at $\delta 3.16$ as also with the carbon at $\delta_{C} 41.1 \mathrm{ppm}$ (C-4). The correlation cross peaks between $\mathrm{H}-23$ and $\mathrm{H}-25$ and $\mathrm{H}-2$ in the NOESY experiment confirmed that the acetoxy function at $\mathrm{C}-1$ was $\beta$-oriented. The proton at $\delta 2.82$ was correlated to the olefinic carbon at $\delta_{\mathrm{C}} 157 \mathrm{ppm}(\mathrm{C}-14)$, three bonds away 
Table 1: ${ }^{13} \mathrm{C}$ NMR data of 1, 2, 3 and their acetates in $\mathrm{CDCl}_{3}(\delta$ in ppm, $125 \mathrm{MHz}$ ).

\begin{tabular}{|c|c|c|c|c|c|c|}
\hline C & 1 & $1 a$ & 2 & $2 a$ & 3 & $3 a$ \\
\hline 1 & 80.6 & 80.7 & 80.9 & 80.9 & 21.5 & 21.5 \\
\hline 2 & 27.8 & 29.8 & 29.9 & 29.7 & 28.6 & 29.0 \\
\hline 3 & 77.2 & 80.6 & 80.6 & 80.8 & 71.8 & 80.5 \\
\hline 4 & 41.1 & 41.5 & 41.1 & 41.3 & 41.9 & 42.0 \\
\hline 5 & 54.5 & 54.6 & 54.6 & 54.6 & 140.7 & 139.0 \\
\hline 6 & 18.4 & 19.5 & 19.5 & 20.1 & 121.7 & 122.0 \\
\hline 7 & 33.3 & 30.2 & 30.2 & 30.2 & 23.5 & 23.4 \\
\hline 8 & 39.6 & 39.9 & 39.6 & 40.1 & 42.7 & 42.9 \\
\hline 9 & 52.6 & 52.7 & 52.6 & 52.8 & 89.5 & 89.5 \\
\hline 10 & 37.6 & 38.1 & 37.6 & 38.1 & 42.7 & 42.8 \\
\hline 11 & 53.4 & 53.4 & 53.4 & 53.3 & 23.4 & 23.5 \\
\hline 12 & 58.2 & 58.3 & 58.2 & 58.4 & 26.4 & 26.4 \\
\hline 13 & 36.5 & 36.4 & 36.4 & 36.4 & 39.7 & 39.8 \\
\hline 14 & 157.1 & 157.1 & 157.2 & 157.1 & 36.9 & 37.0 \\
\hline 15 & 118.9 & 118.9 & 118.9 & 118.8 & 33.9 & 34.0 \\
\hline 16 & 35.7 & 35.9 & 35.7 & 35.8 & 31.9 & 31.8 \\
\hline 17 & 35.4 & 35.8 & 35.8 & 35.8 & 32.3 & 32.5 \\
\hline 18 & 48.1 & 48.5 & 48.1 & 48.6 & 56.1 & 56.3 \\
\hline 19 & 40.2 & 42.1 & 41.5 & 42.1 & 46.2 & 46.1 \\
\hline 20 & 28.7 & 28.8 & 31.9 & 27.5 & 77.2 & 77.3 \\
\hline 21 & 35.7 & 35.9 & 77.2 & 80.1 & 31.9 & 42.5 \\
\hline 22 & 35.6 & 35.7 & 39.6 & 35.1 & 42.7 & 42.5 \\
\hline 23 & 27.0 & 27.1 & 27.0 & 27.2 & 31.9 & 31.8 \\
\hline 24 & 17.0 & 16.5 & 16.7 & 16.7 & 29.3 & 29.5 \\
\hline 25 & 16.6 & 16.5 & 16.5 & 27.5 & 20.3 & 20.3 \\
\hline 26 & 27.0 & 27.5 & 27.8 & 30.1 & 19.8 & 19.9 \\
\hline 27 & 30.2 & 30.2 & 30.2 & 29.8 & 12.1 & 12.3 \\
\hline 28 & 29.9 & 29.8 & 29.9 & 29.9 & 23.1 & 23.2 \\
\hline 29 & 33.6 & 33.1 & 33.3 & 33.3 & 20.0 & 20.1 \\
\hline 30 & 19.5 & 19.5 & 19.5 & 19.5 & 36.1 & 36.2 \\
\hline 1-OAc & $170.8,21.3$ & $170.7,21.2$ & $170.8,21.1$ & $170.8,21.1$ & - & - \\
\hline 3-OAc & - & $170.9,21.4$ & $170.9,21.2$ & $170.9,21.2$ & - & $170.5,21.4$ \\
\hline 21-OAc & - & - & - & $170.1,21.3$ & - & - \\
\hline
\end{tabular}

and allowed joining of spin systems separated by a methylbearing quaternary carbon on one side. The chemical shifts, multiplicity and coupling constants of the A-ring carbinylic protons and an inspection of the molecular models suggested that 1,3-cis-diequatorial functions in ring A caused flattening of this ring.

The spectral patterns of compound $2, \mathrm{M}^{+}$at $m / z$ 556.0739, $\mathrm{C}_{34} \mathrm{H}_{52} \mathrm{O}_{6}$, resembled closely with those of 1a, except that it was shown to possess an extra secondary hydroxy group $\left[v_{\max }\right.$ $\left.3350 \mathrm{~cm}^{-1}, \delta 3.17(\mathrm{dd}, J=11.1 \mathrm{~Hz}, 1 \mathrm{H})\right]$. Its presence was confirmed by acetylation of 2 to $2 \mathrm{a}\left[\delta 2.05(\mathrm{~s}, 9 \mathrm{H}), \delta_{\mathrm{C}} 170.1\right.$, 170.7 and 170.8] and oxidation to diacetoxy ketone $\mathbf{2 b}$ [ $v_{\max }$ $\left.1736,1730,1680 \mathrm{~cm}^{-1}, \delta_{\mathrm{C}} 170.5,170.6,215.2(\mathrm{C}-21)\right]$. The mass spectrum of compound 2 exhibited RDA fragment ions at $m / z 416$ and 140, placing the hydroxy group in ring E. The hydroxy group was placed at C-21 $\alpha$-position $\left(\delta_{C} 77.2\right)[38]$ on the basis of coupling constant of carbinylic proton in the ${ }^{1} \mathrm{H}$ NMR spectrum of $\mathbf{2}$, the downfield chemical shift of C-30 methyl protons ( $\delta$ 1.09) in the spectrum of $\mathbf{2 b}$, and ${ }^{1} \mathrm{H},{ }^{1} \mathrm{H}$, ${ }^{1} \mathrm{H},{ }^{13} \mathrm{C}$ COSY, HMBC and HSQC spectra of 2 which showed long range correlations of the carbinylic proton at $\delta 3.17(\mathrm{H}-21)$ and methyl protons at $\delta 0.87(\mathrm{H}-29)$ as also carbons at $\delta_{\mathrm{C}} 35.7$ (C-16) and 48.1 (C-18).

The ${ }^{1} \mathrm{H}$ NMR, ${ }^{13} \mathrm{C}$ NMR (Table 1) and DEPT $\left(135^{\circ}\right.$ ) spectra of compound 3, $\mathrm{M}^{+}$at $m / z 458.1495, \mathrm{C}_{30} \mathrm{H}_{50} \mathrm{O}_{3}$, revealed that the compound possesses seven tertiary methyls, one of which resonated downfield at $\delta 1.53$; a secondary methyl $[\delta 0.85(\mathrm{~d}$, $J=4.2 \mathrm{~Hz}, 3 \mathrm{H})]$, a trisubstituted double bond [ $v_{\max } 1640,1040$, 
$\left.890 \mathrm{~cm}^{-1}, \delta 5.36(\mathrm{~d}, J=4.7 \mathrm{~Hz}, 1 \mathrm{H})\right]$, and a secondary hydroxy group $\left[v_{\max } 3465 \mathrm{~cm}^{-1}, \delta 3.52\left(\mathrm{dd}, J_{\mathrm{aa}}=7.6 \mathrm{~Hz}, \mathrm{H}-3,1 \mathrm{H}\right)\right]$. On acetylation with $\mathrm{Ac}_{2} \mathrm{O}-\mathrm{C}_{5} \mathrm{H}_{5} \mathrm{~N}$, at room temperature, it afforded monoacetate 3a $\left[1735, \delta 2.05(\mathrm{~s}, 3 \mathrm{H}), \delta_{\mathrm{C}} 170.5\right]$ and on oxidation with $\mathrm{CrO}_{3}-\mathrm{C}_{5} \mathrm{H}_{5} \mathrm{~N}$, it yielded a ketone which gave a positive Zimmermann test for 3-keto group [37] confirming the presence of the C-3 equatorial secondary hydroxy group $\left[\delta_{\mathrm{C}}\right.$ $71.8]$ in $\mathbf{3}$. The mass spectrum of compound $\mathbf{3}$ revealed that the double bond triggered the typical RDA fragmentation of ring $\mathrm{B}$ [39] to give densely populated ion peaks at $\mathrm{m} / z 166$ (ring A) and 292 (rings $\mathrm{C} / \mathrm{D} / \mathrm{E}$ ) placing the double bond at C-5 $\left[\delta_{\mathrm{C}} 122.0\right.$ (C-6), 139.9 (C-5)] [38] and two hydroxy groups in rings C/D/ E. Since the monoacetate $3 \mathbf{a}$ still retained a hydroxy group and its mass spectrum also showed a RDA fragment ion at $m / z 292$, compound 3 , therefore, carried two tertiary hydroxy groups on rings $\mathrm{C} / \mathrm{D} / \mathrm{E}$. The presence of a secondary methyl group together with a pair of doublets at $\delta 1.56$ and 1.85 (d br, $J=$ $10.0 \mathrm{~Hz}, 1 \mathrm{H}$ each, $\mathrm{H}-18$ and $\mathrm{H}-19$ ) showed that the compound belonged to the $\Psi$-taraxastane [35] series. The downfield shift of C-30 methyl singlet ( $\delta 1.53$ ) suggested that one of the tertiary hydroxy groups was at C-20 $\left(\delta_{\mathrm{C}} 77.3\right)$. Had it been on C-19, the ${ }^{13} \mathrm{C}$ signal would have been observed upfield at $\delta_{\mathrm{C}} 73.0-73.2$ [44]. The densely populated ion peaks at $\mathrm{m} / z 221$ (rings A/B) and $203\left(221-\mathrm{H}_{2} \mathrm{O}^{+}\right)$, arising from the fission of 9,11 and 8 , 14 bonds in ring $\mathrm{C}$, together with the downfield carbon signal at $\delta_{\mathrm{C}} 89.5$ placed the second tertiary hydroxy groups at C-9. The structure of compound 3 was further confirmed by ${ }^{1} \mathrm{H},{ }^{1} \mathrm{H}$, ${ }^{1} \mathrm{H},{ }^{13} \mathrm{C} \mathrm{COSY}$ and long range ${ }^{1} \mathrm{H},{ }^{13} \mathrm{C}$ COSY experiments. The presence of the C-9 hydroxy group was proved by linking the carbon signal at $\delta_{\mathrm{C}} 89.5$ to proton signals at $\delta 1.01(\mathrm{C}-25)$ and 0.93 (C-26) in the ${ }^{1} \mathrm{H},{ }^{13} \mathrm{C}$ long-range coupled spectrum. Other data for 1D and 2D NMR spectra of $\mathbf{3}$ were in agreement with the assigned structure.

Comparison of physical characteristics and spectral data of compounds 4 and 5, with those reported in literature [31,32], confirmed them to be friedelin and friedelinol, respectively.

\section{Conclusion}

The compounds 1-5 were, thus, characterized as $1 \beta$-acetoxy$3 \beta$-hydroxy-11 $\alpha, 12 \alpha$-oxido-taraxer-14-ene (1); $1 \beta, 3 \beta$-diacetoxy-21 $\alpha$-hydroxy-11 $\alpha, 12 \alpha$-oxido-taraxer-14-ene (2); $3 \beta, 9 \alpha, 20 \alpha$ trihydroxy- $\Psi$-taraxast-5-ene (3); friedelin (4) and friedelinol (5); respectively. Compounds 1-3 are new triterpenoids while 4 and $\mathbf{5}$ appear to have been isolated for the first time from the genus Euphorbia.

\section{Experimental \\ General procedures}

Melting points were determined in centigrade scale in one end open capillaries on a Büchi 570 melting point apparatus and are uncorrected. IR spectra were recorded on a Perkin-Elmer Paragon-1000 spectrophotometer or an Esquire 3000 spectrometer. ${ }^{1} \mathrm{H}$ and ${ }^{13} \mathrm{C}$ NMR spectra were recorded by a Bruker 500 and $125 \mathrm{MHz}$ instrument using TMS as internal standard and $\mathrm{CDCl}_{3}$ as solvent. High-resolution mass spectra were recorded on a Bruker 400 mass spectrometer. Column chromatography was carried out with Merk silica gel (60-120 mesh). Optical rotation was measured on a Perkin-Elmer polarimeter.

\section{Plant material}

The aerial parts of Euphorbia geniculata (Orteg) were collected from Jammu, (J\&K, India) in July 2013. The specimen was identified by Akhtar H. Malik, Curator, Centre for Biodiversity \& Taxanomy, University of Kashmir (Specimen deposited under accession No. 1850 - KASH Herbarium).

\section{Extraction and isolation}

The shade dried aerial parts of Euphorbia geniculata $(3.0 \mathrm{~kg}$ ) were extracted sequentially with petroleum ether $\left(60-80{ }^{\circ} \mathrm{C}\right)$, ethyl acetate and methanol in a soxhlet apparatus to afford respective extracts which were concentrated under reduced pressure. The ethyl acetate extract (40 g) was subjected to chromatography on silica gel (60-120 mesh, B.D.H.) column using graded solvent systems of petroleum ether-ethyl acetate. The fractions collected with petroleum ether-ethyl acetate (9:1), F-1; (8:2), F-2; (7:3), F-3 and ethyl acetate, F-4, whose components gave green, pink and violet colouration on TLC (silica gel G) plates, after development with cerric ammonium sulfate- $\mathrm{H}_{2} \mathrm{SO}_{4}$, were subjected to re-chromatography. The fraction F-1 on re-chromatography and elution with petroleum ether-dichloromethane (8:2) gave 4 (300 $\mathrm{mg})$ and 5 (410 mg). The fraction F-2 on further chromatography and elution with petroleum ether-dichloromethane (7:3) and (8:4) gave two mixtures. The mixture obtained with petroleum ether-dichloromethane (8:4) was subjected to preparative TLC using petroleum ether-chloroform (19:3) as solvent system to get compound 1 ( $48 \mathrm{mg}$ ). The fraction F-3 on further chromatography and elution with petroleum ether-dichloromethane (8:2) gave compound $\mathbf{2}$ (45 mg). The fraction F-4 on repeated chromatography using the same sequence of graded solvent systems, as for crude extract, gave compound $\mathbf{3}$ (38 mg) with petroleum ether-dichloromethane (3:7) and a mixture containing 3 and $\mathbf{2}$, which was again resolved by preparative TLC using benzene-ethyl acetate (9:1) as solvent system.

Genicunolide A (1): Colourless crystals $\left(\mathrm{CHCl}_{3}-\mathrm{Me}_{2} \mathrm{CO}\right), \mathrm{mp}$ $150{ }^{\circ} \mathrm{C} ;[\alpha]_{\mathrm{D}}{ }^{25}+20.5^{\circ}\left(c 0.50, \mathrm{CHCl}_{3}\right)$; HRMS: $m / z$ (rel. int.) 498.0695 (18) $\left(\mathrm{M}^{+}\right)$(calcd for $\left.\mathrm{C}_{32} \mathrm{H}_{50} \mathrm{O}_{4}, 498.0700\right), 483$ (36.2), 480 (21.4), 456 (28.6), 441 (47.1), 374 (71.3) (RDA, rings $\mathrm{A} / \mathrm{B} / \mathrm{C}), 346$ (57.2), 314 (42.7), 124 (65.8) (RDA, ring E), 108 (100); IR: $v_{\max } 3500(\mathrm{OH}), 3030,2850,1736$ (OAc), 1630, 
1456, 1042, $880 \mathrm{~cm}^{-1} ;{ }^{1} \mathrm{H}$ NMR $\left(500 \mathrm{MHz}, \mathrm{CDCl}_{3}\right) \delta 0.80(\mathrm{~s}$, $3 \mathrm{H}, \mathrm{H}-28), 0.86$ (s, 6H, H-24, H-29), 0.89 (s, 3H, H-30), 0.90 (s, 3H, H-23), 1.01 (s, 3H, H-25), 1.09 (s, 3H, H-26), 1.25 (s, $3 \mathrm{H}, \mathrm{H}-27), 2.06\left(\mathrm{~s}, 3 \mathrm{H}, \mathrm{OCOCH}_{3}\right), 2.31$ (d, $J=6.9 \mathrm{~Hz}, 2 \mathrm{H}$, $\mathrm{H}-16), 2.82$ (d, $J=4.7 \mathrm{~Hz}, 1 \mathrm{H}, \mathrm{H}-12), 3.01$ (d, $J=4.7 \mathrm{~Hz}, 1 \mathrm{H}$, $\mathrm{H}-11), 3.16$ (dd, $J=5.5,8.1 \mathrm{~Hz}, 1 \mathrm{H}, \mathrm{H}-3), 4.53$ (dd, $J=7.4,8.5$ $\mathrm{Hz}, 1 \mathrm{H}, \mathrm{H}-1), 5.56$ (d, $J=5.2 \mathrm{~Hz}, 1 \mathrm{H}, \mathrm{H}-15) ;{ }^{13} \mathrm{C} \mathrm{NMR}$ : Table 1 .

Genicunolide B (2): Colourless crystals $\left(\mathrm{CHCl}_{3}-\mathrm{Me}_{2} \mathrm{CO}\right), \mathrm{mp}$ $160{ }^{\circ} \mathrm{C},[\alpha]_{\mathrm{D}}{ }^{25}+34.2^{\circ}\left(c 0.40, \mathrm{CHCl}_{3}\right)$; HRMS: $m / z 556.0739$ $\left(\mathrm{M}^{+}\right)$(calcd for $\left.\mathrm{C}_{34} \mathrm{H}_{52} \mathrm{O}_{6}, 556.0744\right), 541\left(\mathrm{M}^{+}-\cdot \mathrm{CH}_{3}\right), 514$ $\left(\mathrm{M}^{+}-\mathrm{CH}_{2} \mathrm{CO}\right), 472\left(514-\mathrm{CH}_{2} \mathrm{CO}\right), 454\left(472-\mathrm{H}_{2} \mathrm{O}\right), 416$ (RDA, rings $\mathrm{A} / \mathrm{B} / \mathrm{C}), 356$ (416 - HOAc), 286 (356 - CO $\mathrm{CH}_{2} \mathrm{CO}$ ), 140, 124 (RDA, ring E), 108 (124 - H2O)(100); IR: $v_{\max } 3550,3025,2863,1736$ (OAc), 1730 (OAc), 1625, 1450, 1045, $890 \mathrm{~cm}^{-1} ;{ }^{1} \mathrm{H}$ NMR $\left(500 \mathrm{MHz}, \mathrm{CDCl}_{3}\right) \delta 0.80(\mathrm{~s}, 3 \mathrm{H}$, H-28), 0.87 (s, 6H, H-24, H-29), 0.97 (s, 3H, H-30), 0.98 (s, $3 \mathrm{H}, \mathrm{H}-23), 1.01$ (s, 3H, H-25), 1.09 (s, 3H, H-26), 1.25 (s, 3H, H-27), 2.06 (s, 6H, 2 x OAc), 2.31 (s, 2H, H-16), 2.80 (d, $J=$ $4.7 \mathrm{~Hz}, 1 \mathrm{H}, \mathrm{H}-12), 3.01$ (d, $J=4.8 \mathrm{~Hz}, 1 \mathrm{H}, \mathrm{H}-11), 3.17$ (dd, $J=$ $5.5,11.1 \mathrm{~Hz}, 1 \mathrm{H}, \mathrm{H}-21), 4.53\left(\mathrm{dd}, J=7.6,8.5 \mathrm{~Hz}, 2 \mathrm{H}, \mathrm{H}_{\mathrm{a}}-1\right.$, $\left.\mathrm{H}_{\mathrm{a}}-3\right), 5.56(\mathrm{~d}, J=5.2 \mathrm{~Hz}, 1 \mathrm{H}, \mathrm{H}-15) ;{ }^{13} \mathrm{C}$ NMR: Table 1.

Genicunolide C (3): Colourless needles, mp 210-211 ${ }^{\circ} \mathrm{C}$, $[\alpha]_{\mathrm{D}}{ }^{25}+30.3^{\circ}\left(c 0.3, \mathrm{CHCl}_{3}\right)$; HRMS: $m / z 458.1495\left(\mathrm{M}^{+}\right)$ (calcd for $\left.\mathrm{C}_{30} \mathrm{H}_{50} \mathrm{O}_{3}, 458.1500\right)\left(\mathrm{M}^{+}\right), 443\left(\mathrm{M}^{+}-\mathrm{CH}_{3}\right), 440$ $\left(\mathrm{M}^{+}-\mathrm{H}_{2} \mathrm{O}\right), 425\left(\mathrm{M}^{+}-\mathrm{CH}_{3}-\mathrm{H}_{2} \mathrm{O}\right), 413\left(\mathrm{M}^{+}-\right.$ $\mathrm{CH}_{3} \mathrm{CH}={ }^{+} \mathrm{OH}$ ), 292 (RDA, rings $\mathrm{C} / \mathrm{D} / \mathrm{E}$ ), 237 (RDA, rings $\mathrm{D} /$ E), 221, 203, 166 (RDA, ring A), 163, 107, 83, 45 (100); IR: $v_{\max } 3580,3465,1640,1445,1040,1025,890 \mathrm{~cm}^{-1}$; ${ }^{1} \mathrm{H}$ NMR $\left(500 \mathrm{MHz}, \mathrm{CDCl}_{3}\right) \delta 0.68$ (s, 3H, H-28), 0.79 (s, 3H, H-27), 0.81 (s, 3H, H-23), 0.85 (d, J=4.2 Hz, 3H, H-29), 0.90 (s, 3H, H-24), 0.93 (s, 3H, H-26), 1.01 (s, 3H, H-25), 1.53 (s, 3H, H-30), 1.56 (d br, $J=10.0 \mathrm{~Hz}, 1 \mathrm{H}, \mathrm{H}-18), 1.85$ (d br, $J=10.0$ $\mathrm{Hz}, 1 \mathrm{H}, \mathrm{H}-19), 2.28$ (s, 2H, H-7), 3.52 (dd, $J=4.8,7.6 \mathrm{~Hz}, 1 \mathrm{H}$, H-3), 5.36 (d, $J=4.7 \mathrm{~Hz}, 1 \mathrm{H}, \mathrm{H}-6)$; ${ }^{13} \mathrm{C}$ NMR: Table 1.

Acetylation of 1, 2 and 3: Compounds 1, 2 and 3 (20 mg each) were dissolved separately in $\mathrm{C}_{5} \mathrm{H}_{5} \mathrm{~N}(2 \mathrm{~mL})$ and $\mathrm{Ac}_{2} \mathrm{O}(2 \mathrm{~mL})$ was added. The reaction mixtures were left overnight, diluted with water and extracted with chloroform. The chloroform solutions were washed with $5 \% \mathrm{HCl}-\mathrm{H}_{2} \mathrm{O}$ solution $(10 \mathrm{~mL}$ each time) and dried over anhydrous $\mathrm{K}_{2} \mathrm{CO}_{3}$. After removal of the solvent, the crude acetates were purified by column chromatography on silica gel using petroleum ether-benzene $(9: 1,7: 3$ and $1: 1 \mathrm{v} / \mathrm{v}$ ) when 1a, 2a and 3a (18 mg, $17 \mathrm{mg}$ and $19 \mathrm{mg}$, respectively) were recovered.

Oxidation of 1 and 2: Compound $\mathbf{1}(12 \mathrm{mg})$ and compound 2 $(15 \mathrm{mg})$ were dissolved separately in $\mathrm{C}_{5} \mathrm{H}_{5} \mathrm{~N}(1 \mathrm{~mL})$ and treated with freshly prepared $\mathrm{CrO}_{3}-\mathrm{C}_{5} \mathrm{H}_{5} \mathrm{~N}$ complex. The reaction mixtures were left overnight, diluted with water $(10 \mathrm{~mL})$ and extracted with chloroform $(3 \times 20 \mathrm{~mL})$. The chloroform layer was washed with water, $0.1 \mathrm{~N} \mathrm{HCl}$, water and dried over anhydrous $\mathrm{MgSO}_{4}$. After removal of the solvent, the residues were purified by column chromatography over silica gel using a petroleum ether-benzene $(1: 1 \mathrm{v} / \mathrm{v})$ solvent system, and crystallized from $\mathrm{CHCl}_{3}-\mathrm{Me}_{2} \mathrm{CO}$.

\section{Supporting Information}

\section{Supporting Information File 1}

Spectral data of genicunolide A acetate (1a), genicunolide

$B$ acetate (2a), genicunolide $C$ acetate (3a),

oxogenicunolide A (1b), oxogenicunolide B (2b), friedelin

(4) and friedelinol (5).

[http://www.beilstein-journals.org/bjoc/content/

supplementary/1860-5397-11-291-S1.pdf]

\section{Acknowledgements}

The authors are highly thankful to the Director of NIT Srinagar for providing all types of facilities during the work. One of the authors, Alia Farozi, would like to thank the Ministry of Human Resource Development (MHRD) New Delhi for providing the Institute Fellowship to carry out this work.

\section{References}

1. Stebbins, G. L.; Hoogland, R. D. Plant Syst. Evol. 1976, 125, 139-154.

2. Evans, F. J.; Taylor, S. E. Progress in the Chemistry of Organic Natural Products; Springer-Verlag: New York, 1983; Vol. 44.

3. Singla, A. K.; Pathak, K. Fitoterapia 1990, 61, 483-516.

4. Upadhyay, R. R.; Zarintan, M. H.; Ansarin, M. Planta Med. 1976, 30 , 32-34. doi:10.1055/s-0028-1097689

5. Upadhyay, R. R.; Zarintan, M. H.; Ansarin, M. Planta Med. 1976, 30 , 196-197. doi:10.1055/s-0028-1097717

6. Upadhyay, R. R.; Mohaddes, G. Curr. Sci. 1987, 56, 1058-1059.

7. Abdelgaleil, S. A. M.; Kassem, S. M. I.; Doe, M.; Baba, M.; Nakatani, M. Phytochemistry 2001, 58, 1135-1139. doi:10.1016/S0031-9422(01)00393-4

8. Hohmann, J.; Rédei, D.; Evanics, F.; Kálmán, A.; Argay, G.; Bartók, T. Tetrahedron 2000, 56, 3619-3623. doi:10.1016/S0040-4020(00)00278-7

9. Hohmann, J.; Molnár, J.; Rédei, D.; Evanics, F.; Forgo, P.; Kálmán, A.; Argay, G.; Szabó, P. J. Med. Chem. 2002, 45, 2425-2431. doi:10.1021/jm0111301

10. Hohmann, J.; Rédei, D.; Forgo, P.; Molnár, J.; Dombi, G.; Zorig, T. J. Nat. Prod. 2003, 66, 976-979. doi:10.1021/np030036f

11. Ravikanth, V.; Reddy, V. L. N.; Rao, T. P.; Diwan, P. V.; Ramakrishna, S.; Venkateswarlu, Y. Phytochemistry 2002, 59, 331-335. doi:10.1016/S0031-9422(01)00461-7

12. Wang, L.-Y.; Wang, N.-L.; Yao, X.-S.; Miyata, S.; Kitanaka, S. J. Nat. Prod. 2002, 65, 1246-1251. doi:10.1021/np0200921 
13. Öksüz, S.; Gürek, F.; Gil, R. R.; Pengsuparp, T.; Pezzuto, J. M.; Cordell, G. A. Phytochemistry 1995, 38, 1457-1462. doi:10.1016/0031-9422(94)00806-5

14. Ahmad, V. U.; Hussain, H.; Hussain, J.; Jassbi, A. R.; Bukhari, I. A.; Yasin, A.; Choudhary, M. I.; Dar, A. Z. Naturforsch., B: J. Chem. Sci. 2002, 57, 1066-1071.

15. Jassbi, A. R. Phytochemical Investigations on Some Medicinal Plants from Families Euphorbiaceae and Lamiaceae. Ph.D. Thesis, HEJ Research Institute of Chemistry, Karachi University, Pakistan, 2000.

16. Jassbi, A. R.; Zamanizadehnajari, S.; Tahara, S. Z. Naturforsch., C. J. Biosci. 2004, 59, 15-18.

17. Ahmad, V. U.; Zahid, M.; Khan, T.; Asim, M.; Ahmad, A. Proc. Pak. Acad. Sci. 2002, 39, 201-205.

18. Ulubelen, A.; Aynehchi, Y.; Halfon, B. Doga: Tip Eczacilik 1986, 10, 211-213. Chem. Abstr. 1986, 105, 168929v.

19. De, P. T.; Urones, J. G.; Marcos, I. S.; Basabe, P.; Cuadrado, M. J. S.; Moro, R. F. Phytochemistry 1987, 26, 1767-1776. doi:10.1016/S0031-9422(00)82286-4

20. Anjaneyulu, V.; Rao, G. S.; Connolly, J. D. Phytochemistry 1985, 24, 1610-1612. doi:10.1016/S0031-9422(00)81079-1

21. Öksüz, S.; Shieh, H.-L.; Pezzuto, J. M.; Özhatay, N.; Cordell, G. A. Planta Med. 1993, 59, 472-473. doi:10.1055/s-2006-959736

22. Pousset, J.-L.; Poisson, J. Tetrahedron Lett. 1969, 10, 1173-1174. doi:10.1016/S0040-4039(01)87834-5

23. Bhakuni, D. S.; Joshi, P. P.; Uprety, H.; Kapil, R. S. Phytochemistry 1974, 13, 2541-2543. doi:10.1016/S0031-9422(00)86933-2

24. Bindra, R. S.; Satti, N. K.; Suri, O. P. Phytochemistry 1988, 27, 2313-2315. doi:10.1016/0031-9422(88)80150-X

25. Nadkarni, A. K. Indian Materia Medica; Popular Prakashan: Bombay, India, 1976

26. Jafri, S. M. H. Flora of Karachi; The Book Corp.: Karachi, 1966.

27. Sharma, B. M.; Kachroo, P. Flora of Jammu and Plants of Neighbourhood; Narosa Publications: India, 1981

28. Ismail, S. I.; el-Missiry, M. M.; Hammoida, F. M.; Rizk, A. M. Pharmazie 1977, 32, 538-542.

29. Rizk, A. M.; Hammouda, F. M.; el-Missiry, M. M.; Radwan, H. M.; Evans, F. J. Phytochemistry 1985, 24, 1605-1606. doi:10.1016/S0031-9422(00)81076-6

30. Tripathi, R. D.; Tiwari, K. P. Phytochemistry 1980, 19, 2163-2166. doi:10.1016/S0031-9422(00)82215-3

31. Klass, J.; Tinto, W. F.; McLean, S.; Reynolds, W. F. J. Nat. Prod. 1992, 55, 1626-1630. doi:10.1021/np50089a010

32. Ho, L.-K.; Chang, C.-R.; Chang, Y.-S. J. Chin. Chem. Soc. 1995, 42, 93-95. doi:10.1002/jccs.199500016

33. Brieskorn, C. H.; Capuano, L. Chem. Ber. 1953, 86, 866-873. doi:10.1002/cber.19530860709

34. Hashimoto, Y. An. Acad. Bras. Cien. 1970, 42 (suppl.). Chem. Abstr. 1971, 75, 58443.

35. Razdan, T. K.; Kachroo, V.; Harkar, S.; Koul, G. L. Tetrahedron 1982, 38, 991-992. doi:10.1016/0040-4020(82)85077-1

36. Williams, D. H.; Bhacca, N. S.; Djerassi, C. J. Am. Chem. Soc. 1963, 85, 2810-2813. doi:10.1021/ja00901a031

37. Fried, J.; Edwards, J. A. Organic reactions in steroid chemistry; van Nostrand Reinhold: New York, 1972.

38. Mahato, S. B.; Kundu, A. P. Phytochemistry 1994, 37, 1517-1575. doi:10.1016/S0031-9422(00)89569-2

39. Budzikiewicz, H.; Wilson, J. M.; Djerassi, C. J. Am. Chem. Soc. 1963, 85, 3688-3699. doi:10.1021/ja00905a036
40. Tanaka, R.; Matsunaga, S. Phytochemistry 1988, 27, 3579-3584. doi:10.1016/0031-9422(88)80772-6

41. Ito, K.; Lai, J. Yakugaku Zasshi 1978, 98, 1285-1287.

42. Matsunaga, S.; Tanaka, R.; Akagi, M. Phytochemistry 1988, 27 , 535-537. doi:10.1016/0031-9422(88)83136-4

43. Savona, G.; Bruno, M.; Rodriguez, B.; Marko, J. L. Phytochemistry 1987, 26, 3305-3308. doi:10.1016/S0031-9422(00)82493-0

44. Rai, N.; Singh, J. Indian J. Chem., Sect. B 2001, 40, 320-323.

\section{License and Terms}

This is an Open Access article under the terms of the Creative Commons Attribution License

(http://creativecommons.org/licenses/by/2.0), which permits unrestricted use, distribution, and reproduction in any medium, provided the original work is properly cited.

The license is subject to the Beilstein Journal of Organic Chemistry terms and conditions:

(http://www.beilstein-journals.org/bjoc)

The definitive version of this article is the electronic one which can be found at: doi:10.3762/bjoc. 11.291 